\title{
The Intersection of Race and Gender in Leadership of Co-operatives: of Whom, by Whom, and for Whom?
}

\author{
Ushnish Sengupta
}

\begin{abstract}
This paper describes the intersection of class, gender and race in the leadership of co-operatives in North America. Movement of labour across North American borders changes the membership of co-operatives as well as the leadership and formation of co-operatives. The socio-economic shifts that affect co-operatives are also accompanied by marginalisation of particular populations. Although women and racial minorities have made some advances in equity in co-operatives, racialized women in particular are not represented in leadership positions in co-operatives in proportion to membership in the broader population. In this context, international co-operative principles remain ideals to aspire to rather than a reality in practice. On an optimistic note, co-operatives continue to be more egalitarian organisations than other types of organisations and therefore have the potential for leading as positive role models, addressing the intersection of gender and race for other organisations to follow.
\end{abstract}

\section{Introduction}

This paper describes the intersection of gender and race in the leadership of co-operatives in North America. The paper utilises an intersectional approach where the intersections of gender, race and class result in specific experiences and barriers that are different from the analysis of class, gender and race in isolation (Crenshaw, 1995). In other words, class analysis without gendered analysis, and gendered analysis without race analysis is necessarily incomplete. Co-operative organisations provide a unique opportunity for analysis of leadership by gender, race, and class since co-operatives exist in multiple countries and industries, have plural organisational forms (producer, consumer, multi-stakeholder), and at the same time follow a set of core international co-operative principles across all co-operatives (International Co-operative Alliance, 2015a). Co-operatives and co-operative principles provide unique possibilities for equity for racialized women. Co-operatives, as a group of organisations deserve commendation for collectively agreeing to including gender, social, racial, political and religious non-discrimination as the first co-operative principle. At the same time, it is useful to examine the differences between principle and practice, rhetoric and reality, in gendered and racialized differences in co-operatives. Since co-operative principles set high aspirational goals for all co-operatives, the identification of differences in experience of implementation is useful in identifying opportunities and pathways for improvement.

Co-operatives have historically been a class based organisational response to the economic inequities between workers and owners resulting from the growth of large private corporations (Curl, 2012; MacPherson, 1979). With the "one member, one vote" principle, as opposed to votes based on number of shares, co-operatives provide a more egalitarian form of organisation that enables greater decision making capability by workers and consumer members of the co-operative. At the same time, viewing co-operatives as organisations solely from a class based perspective is necessarily incomplete without an analysis based on gender and race. If co-operative leadership is gendered in a particular way, with men dominating leadership positions, there is work to be done in increasing gender equity in co-operatives. Similarly if co-operative leadership is gendered and racialized in a particular way, with underrepresentation of racialized women in the leadership of co-operatives, there is work to be done in simultaneously dealing with gender and race equity issues in co-operatives. The available evidence points to underrepresentation of women in leadership of co-operatives (Schincariol McMurtry and McMurtry, 2015) and an underrepresentation of racialized women in leadership of co-operatives (Findlay and Wuttunee 2007). 
Co-operatives are one of the few groups of organisations that have adopted a set of equity related principles internationally, across national jurisdictional boundaries. The corresponding analysis of gendered and racialized leadership in co-operatives in this paper is therefore crossjurisdictional and international in scope. In this paper, the area for analysis for gendered and racialized leadership in co-operatives is North America, a region connected by geography, history and trade.

\section{International Co-operative Principles}

The Co-operative Principles, which were updated in 1995, remain aspirational ideals rather than everyday practices. The Guidance Notes to the Co-operative Principles explicitly note the slow tangible progress towards gender equity in co-operatives (International Co-operative Alliance, 2015b). In a study of co-operatives in the USA, Miller (2012) finds that although co-operatives are more egalitarian forms of organisation, a number of gendered inequalities persist, particularly in decision-making and leadership. Additional research on co-operatives in the USA indicates that in a changing immigration and employment socio-economic context, co-operatives can either implicitly reinforce or explicitly resist gender and race stratification that exists in broader society (Meyers and Vallas, 2016). This paper argues in particular that the first co-operative principle, Voluntary and Open Membership, requires a greater level of effort for implementation of equity principles into everyday practice, specifically with respect to leadership in co-operatives by women and racialized minorities. The International Co-operative Alliance (2015a) describes the principle of Voluntary and Open Membership as follows:

Co-operatives are voluntary organisations, open to all persons able to use their services and willing to accept the responsibilities of membership, without gender, social, racial, political or religious discrimination. (International Co-operative Alliance, 2015a)

In the context of this paper the first co-operative principle is interpreted to include leadership as a part of membership. In co-operatives, decision-making is not only a responsibility, but also a right for all members. Therefore, membership broadly involves decision-making and leadership. This paper argues that the ability to start, manage and maintain co-operatives is a necessary element of leadership. Therefore the first co-operative principle is interpreted to include:

- Opportunity for membership in different co-operatives for racialized women.

- Opportunity for different co-operative job and task responsibilities for racialized women.

- Opportunity for different management and leadership responsibilities for racialized women.

- Opportunity for starting up new co-operatives for racialized women.

Barriers to leadership opportunities for racialized women are experienced both in existing co-operatives and in starting up new co-operatives (Neal, 1998). Although the majority of literature on gender and racial equity issues focuses on existing co-operatives, significant gendered and racialized gaps exist in the ability to, and need for starting new co-operatives (Findlay et al, 2014; Harris and McLeod Rogers, 2014). Women leading co-operatives will form different types of co-operatives than men leading co-operatives in the same industry (Radel, 2011). Additionally racialized women leading co-operatives will form different types of organisations than traditional co-operatives, providing for enriched plurality of organisational forms required for addressing complex socio-economic problems (Schneiberg, 2010).

\section{Definitions}

For consistency, this paper intentionally utilises the terms "gender" and "racial" from the co-operative principles. Gender analysis in this paper refers the different organisational 
experiences between men and women in co-operatives. Racialized minorities, in the context of this paper, refer to groups that are a racial minority in their respective countries, such as immigrant, diaspora, and Indigenous ${ }^{1}$ communities. The term "racialized" is used to emphasise race as a social construction rather than a biological or cultural characteristic. The term "racialized women" in this paper refers to individuals who self identify as women and belong to a racialized minority in the primary country of residence.

\section{Intersectionality of Gender and Race}

The majority of literature on gender in co-operatives is disconnected from the analysis of race. The intersection of gender and race is important for analysis, as advances made in organisational leadership by women do not necessarily translate to advances for all women, particularly racialized women. In a broad report on the American environmental non-profit organisations, Taylor (2014) indicates that women have made gains in leadership, but racialized minorities have not made similar gains. If there is no explicit effort to understand the intersections of gender and race in co-operatives, a similar process privileging advances by women without advances by racialized minorities can occur within co-operatives. Acker (2006) utilises the term Inequality Regimes to describe the combined intersections of class, gender and race that result in inequities in organisations, and point out that: "Even organisations that have explicit egalitarian goals develop inequality regimes over time ..." (Acker, 2006: 443). Gender and racial inequalities exist not only within individual co-operatives, but can also exist between co-operatives (Acker, 2000) where smaller co-operatives are led by racialized women, whereas larger more financially stable co-operatives are led by men. Sumner (2005) for example describes the changes in the agriculture industry in Canada, concluding that women tend to own smaller organic farms, while men tend to own larger commercial farms. Moreover, in a study of co-operatives in Canada female co-operative leaders expressed the dynamic nature of gendered leadership whereby "Men take over co-operatives started by women as soon as they become successful” (Lans, 2004: 77).

An international survey on gender in co-operatives indicates that although gender equity has increased in co-operatives, women are still underrepresented in higher management and at board levels, and there is uneven progress between sectors and geographies (Schincariol McMurtry and McMurtry, 2015). Schincariol McMurtry and McMurtry (2015) point out that women's leadership is lower than average in co-operatives in North America and the Middle East. The report's finding of underrepresentation of women in leadership positions in co-operatives is consistent with earlier local small sample based studies in Canada (Theis and Ketilson, 1994) and the USA (Miller, 2012). In concordance with the concept of Inequality Regimes used by Acker (2006) to describe the combined intersections of class, gender and race that result in inequities in organisations, the analysis of these intersections necessarily starts with gender. Research on co-operatives from a perspective of racial and ethnic differences are few and far between (Ketilson and MacPherson, 2001; Nembhard, 2004), while research on intersectional experiences of racialized women in co-operatives are even rarer (Findlay and Wuttunee, 2007; Nembhard and Marsh, 2012). It is therefore this area of intersectionality between gender and race in co-operatives that requires greater analysis and research.

\section{Benefits of Gender and Racial Equity}

There are a number of benefits of gender and racial diversity in all types of organisations. McKinsey, respected by the business sector as one of the world's most prestigious consulting firms (Adams, 2011), studied gender and racial diversity across a broad group of organisations in a number of countries, and concluded there is a significant positive relationship between organisational gender and racial diversity and financial performance (Hunt et al, 2015). Truehaft, Scoggins and Tran (2014) argue that reducing racial inequality is beneficial not only for racialized communities, but for the broader economy in the United States. Corresponding 
to this demand, co-operatives supply an organisational form offering greater possibility for gender and racial equity. Nembhard (2004) argues, for example, that co-operatives are a useful vehicle for achieving economic equity for African-American communities. Nembhard and Marsh (2012) conclude that financial co-operatives such as credit unions are compatible with the needs of African-American women. In a similar vein, Ketilson and MacPherson's (2001) research on Indigenous co-operatives in Canada proposes that co-operatives are compatible with Indigenous community goals. Furthermore, Findlay and Wuttunee (2007) indicate that cooperative principles are compatible with Indigenous women's goals. Theis and Ketilson (1994), and Harris and McLeod Rogers (2014) broaden this discussion further and provide support for co-operatives as an employment solution for a group marginalised by class, race and gender in Canada, Indigenous women who are incarcerated, or transitioning out of incarceration.

\section{Geography of Co-operatives in North America}

Co-operatives are one of the few groups of organisations that have adopted a set of equity related principles internationally, across national jurisdictional boundaries. Therefore a useful analysis of gendered and racialized leadership in co-operatives is intra-continental, crossjurisdictional and international in scope and reveals patterns that are not discernible from single country studies. In this paper, the area for analysis for gendered and racialized leadership in co-operatives is therefore extended to North America, a region connected by geography, history and trade. North America includes the USA, Canada, Mexico, Guatemala, Honduras, El Salvador, Nicaragua among other countries. From an Indigenous worldview, North America is a connected continent in the shape of a turtle, therefore described as Turtle Island (Corntassel, 2008). North America has a number of commonalities other than a connected geography, such as a history of colonisation, slavery and immigration resulting in minority racialized communities with specific experiences. The North American Free Trade Agreement has also created stronger socio-economic ties between the USA, Canada and Mexico in particular, the three largest economies and most populated countries in the region. Co-operatives trading in goods and services have been negatively and positively affected by the increase of trade in the region. A constantly changing political economy can have geographical, gendered and racialized effects on co-operatives (Blaszak, 2000; Nembhard, 2004).

The North American context of co-operatives involves the political economy of co-operatives. As described by Graefe (2006), social economy organisations, which include co-operatives, can "flank" (work with) neoliberal economies, and simultaneously work in opposition to neoliberal economies. Fair Trade co-operatives, for example, are one response to laissez-faire neoliberal trade policies, countering the practice of allocation of an extremely low price for producers and allocating a high profit to middlemen traders. Fair Trade co-operatives are therefore primarily a class response to economic inequities, addressing supply chain economic inequities between producers, consumers and intermediaries. The following section describes the interaction of class, gender and co-operatives in the Southern countries of North America.

\section{Flanking and Developing Alternatives to Neoliberal Economies}

Nicaragua has had a history of post Sandinista conflict support for co-operatives by the government who envisioned co-operatives to be aligned with post conflict government ideology (Mayoux, 1992). Mayoux (1992) indicates that post conflict women-led co-operatives were gendered along traditional roles of food preparation and clothing production. Mayoux (1993) subsequently argues that feminist causes including gender equity were not supported in overall co-operative structures. Bacon (2010) provides a case study of a coffee growing co-operative in Nicaragua finding that working in a fair trade co-operative does not necessarily translate into increased empowerment for women.

Susman and Schneider (2008) describe how free trade zones in Nicaragua exacerbate economic inequalities. Co-operative organisations participating in these zones can moderate 
inequalities, but face strong institutional barriers that limit the type of organisation and line of business (Susman and Schneider 2008). Fisher (2013) describes the uneven power dynamics between a Nicaraguan fair trade clothing co-operative and a retailer in the United States, suggesting that class and race dynamics eventually led to a breakdown in the business relationship and partnership.

Neu and Quantanilla (2008) provide a case example from El Salvador of a fair trade clothing co-operative providing products to a Canadian distributor. In this instance, the co-operative was setup by women who previously worked in a maquila factory (which are designed and set up to manufacture products for export taking advantage of low-cost labour) whose experience at the maquila factory involved a high level of restriction on autonomy and decision-making. Although setting up a co-operative enabled more autonomy and decision making, it brought other challenges. The women found, for example, that producing goods for a global market demands a particular type of management education that they acquired over time. Similarly, Olson (1999) describes artisanal co-operatives in Guatemala where highly skilled women had to deal with changing global market demands and changing consumer tastes and styles, which often conflicted with women's weaving craft traditions.

Government policy towards investment in an economy based on maquila factories has also been resisted by indigenous women in Guatemala who remain in highlands or squatter settlements around growing cities without working in maquilas. Eccarius-Kelly (2006) for example, describes the formation of co-operatives on the margins of cities in Guatemala by indigenous Mayan women displaced by conflict and ecological disasters. Guatemalan government support for Indigenous women's groups in particular has been limited as indigenous women's groups are thought to be subversive towards government policy. The limitations of government support have further constrained women's attempts to create community-oriented businesses such as co-operatives based on traditional Mayan sociocultural practices (EccariusKelly, 2006).

The common thread from the research of women and co-operatives of Nicaragua, El Salvador, and Guatemala indicates that an increase in free trade, and even fair trade co-operatives does not necessarily translate to gender equity for women. In other words addressing an economic or class-based inequity through the development of co-operatives does not always translate to positive effects on gender and racial inequities.

\section{Co-operatives Led by Women in Mexico}

One of the common experiences of North America is the experience of colonisation. The structure and process of colonisation racializes, and culturally and economically marginalises, indigenous communities. Schmidt (2006) provides an analysis of the intersection of gender and race, describing the experiences of indigenous women in co-operatives in Mexico and argues that indigenous communities in Mexico have developed traditional communal structures in response to ecological crisis before colonialism. The existence of traditional communal structures has enabled Indigenous women to avoid top down approaches that impose nonindigenous systems. At the same time indigenous women have adopted more non-hierarchical co-operative structures that have brought back gender equity in decision-making, as well as traditionally sustainable industries. Here, revitalising traditional ecological practices has led to reforestation of abandoned fields, reversing the degradation of the surrounding environment (Schmidt 2006).

Peterson (2014) describes a Mexican women-led aquaculture co-operative that created new possibilities for the women beyond household, regional, and national boundaries. Peterson (2014) found that sustainable harvesting was a 'normal' way of doing business for women, and obtaining internationally recognised labelling is a subsequent administrative step. Another example is provided by Giovannini (2015) who describes the conscious incorporation of buen vivir into Indigenous organisations, in the Chiapas region of Mexico, where buen vivir involves 
the good life, living in harmony with nature and with others. Indigenous communities in Mexico and particularly indigenous women have shown a high level of resilience and flexibility in combining traditional community principles with new organisational forms such as co-operatives. In a parallel North American indigenous experience, Mahood (2010) found that an Inuit soapstone carving industry was enabled in Canada through co-operatives.

As well as co-operatives being an adaptable organisational form for indigenous communities, co-operatives are also a site of resistance and class, gender and racial conflict. Stephen (2005) describes an indigenous women's textile producing co-operative in Mexico as a response to neoliberalism when the initial implementation of the North American Free Trade Agreement (NAFTA) benefited few but not all community members. Although formation of indigenous women's co-operatives enabled greater economic and racial equity, co-operatives challenged traditional community gendered roles (Stephen, 2005).

Eber (1999) summarises the experience of Indigenous women led co-operatives during the period of intense armed conflict in the Chiapas region of Mexico in the mid 1990s indicating that membership in a co-operative endangered women's lives by association with the Zapatista independence movement. Even so, indigenous women voluntarily participated in co-operatives as part of local social movements. Interestingly, Eber (1999) points out that early forms of craft co-operatives in Mexico were set up by the central government to encourage an indigenous crafts economy as well as increase earnings of tourist dollars.

Co-operatives in Mexico have had mixed results in terms of class and gender interactions. A study by Isaac (1995) indicates class stratification in a Mexican co-operative, between women who can weather fluctuations in co-operative income due to other sources of household income, versus women who are primarily dependent on income from co-operative enterprise. Mutersbaugh (2002) describes the creation of a 'co-operative class' within a Mexican village. In this example, co-operative members supported electrification and a particular plan for urban development, whereas independent villagers opposed the co-operative land use plans. Similar splits are found in research undertaken by Mitchell (1996) who describes how Arctic co-operatives created hierarchical income-based class structures within Indigenous societies, which were less hierarchical before wage-based economies were imposed on them. Other changes in interactions between co-operative members and non-co-operative members in indigenous communities have also been noted. For example, Gitter, Weber, Barham, Callenes and Valentine (2012) report an increase in the numbers of years of formal schooling for women from families involved in a Fair Trade co-operative in Mexico. While Mutersbaugh (1999) describes the development of a women led co-operative bakery in Oaxaca as a form of resistance to men's attempts to incorporate women's labour into changing production processes where previous traditional Indigenous agro-technology separated men and women's crops and related agricultural tasks. In addition, new technology has helped alleviate manual labour for men but not women.

Co-operatives like many other organisational forms can serve multiple purposes. When co-operatives are implemented top down by governments, they serve as instruments of government policy. Alternatively when co-operatives are developed from the grassroots they can be part of a larger social justice movement strategy. In some cases co-operatives developed by governments for a particular purpose can be transformed by the community that owns the co-operative to meet their own contemporary purposes (see for example, Sengupta (2015) who provides an analysis of indigenous co-operatives in Canada and the constantly changing multiplicity of purposes behind different co-operatives).

\section{Co-operatives Employing Immigrant Women in the United States}

Racialized communities in the US and Canada include indigenous communities, descendants of slavery, and immigrant diasporas. Schmidt (2006) argues that migrants, who are ethnic minorities or indigenous communities in their country of origin, continue to experience marginality as 
temporary or permanent immigrants to the US. This has an historical and contemporary relevance for co-operatives. McElhinny (1998) describes a co-operative in US where facilitators were European-American, and participants or employees were racialized women. McElhinny (1998) found that differences in class and race between the facilitators and lower class racialized women resulted in differences in the identification of problems and relative importance of problems.

More recently, Estey (2011) describes the BeyondCare co-operative employing immigrant women in New York, and Gute, Siqueira, Goldberg, Galvão, Chianelli and Pirie (2009) describe the Vida Verde Women's Co-op employing Brazilian immigrants. Both of these co-operatives are formed out of the need to organise workers who are in a stronger position as a group to negotiate with employers instead of as individuals. At the same time, many co-operatives organised for racialized women, are described by Martin (2011) as a strategy for organising employment of precarious migrant labour. Martin (2011) categorises co-operatives as an organisational strategy, which enables greater control of conditions of work, but also raises conditions possible for of self-exploitation, high time investment from staff, and a high failure rate. The latter has been shown in relation to historical attempts to develop multi-racial co-operatives in USA have failed due to larger economic political and cultural trends (Gessler, 2015). The phenomenon of migrant based co-operatives in the United States, however, is relatively new and the test of time will indicate if they overcome the risk of failure. In order to do this, Vargas-Cetina (2005) argues in order to avoid becoming ephemeral or temporary, co-operative organisations have to reinvent themselves constantly, and keep up with global and local challenges, and more specifically that:

The fight for ethnic identity, for indigenous rights, for greater opportunities against poverty and marginalisation, is a struggle that transcends the economic objectives of co-operatives and collectives and lends new meanings to these associations. (Vargas-Cetina, 2005: 234)

\section{Conclusion}

The most encouraging aspect of co-operatives developed by racialized women may be that they are different from co-operatives developed by men. Trauger, Sachs, Barbercheck, Brasier and Kiernan (2010) argue that women are rejecting economic market and profit orientation, and that by developing alternative economic practices via co-operatives, they emphasise community, family and innovative business models. Schmidt (2006) and Peterson (2014) describe indigenous women who have combined the organisational form of co-operatives with traditional sustainable ecological practices. Indigenous women across North America have been at the forefront of combining social justice with environmentally sustainable movements based on the traditional relationship with their land. Pattison and Findlay (2010) for example describe the Northern Saskatchewan Trappers Association Co-operative (NSTAC) where trapping is a traditional indigenous activity related to livelihood and is treated by NSTAC members not as a form of resource extraction but, rather, as a form of stewardship of the land, implementing sustainable practices over multiple generations. Where these values and objectives are combined as with the earlier example of organic farming (McMahon, 2011) women are more involved and hold - in the case of organic farming in Canada - the majority of executive positions at local, provincial, and national levels.

Meyers and Vallas (2016) researched two co-operatives in the US that were started primarily by white men, but now employ racialized men and women, many of whom are migrants from Central America. They conclude that the co-operative that took an explicit and active approach to addressing gender and race issues, has been more successful in achieving gender and race equity. Yet without explicit attention to gender and race the default situation is towards racial and gendered hegemony by dominant groups. Van Vliet (2006) argues that the co-operative sector mirrors dominant cultural attitudes towards women. In addition, Van Vliet (2006) also argues that co-operatives as a sector does not challenge socio-economic structures that maintain class, race and gender inequalities. In this regard, lessons may come from the experience of racialized women who work in the non-profit sector. 
A broader critique of the non-profit sector and its ethno-racial diversity is provided by Incite! Women of Color Against Violence (2007). Similar to the discussion above, Incite makes the case that mainstream civil sector organisations often act against the interests of grassroots organisations, since the societal changes demanded by grassroots require genuine changes in power structures. Incite (2007) highlights the efforts of racialized feminist groups and the suppression of efforts by mainstream feminist organisations. The arguments presented by Incite (2007) apply to co-operatives, where mainstream co-operative organisations led mostly by men do not want to alter gender and racial power structures. Furthermore, mainstream co-operatives led by White women do not necessarily want to alter racial power structures. Acker (2005) provides a recommended solution directing that calls to address race issues need to start with addressing gender issues, and recognising intersectionalities with class and race. Spaces and resources providing support systems need to be provided so that racialized women can develop their own organisations. As described in this paper, co-operatives developed by racialized women demonstrate social justice and environmental sustainability practices that are not found in all co-operatives. Many of the organisations developed by racialized women may not be incorporated formally as co-operatives, but may have structures similar to co-operatives (Kinonda-niimi Collective, 2014). Co-operatives therefore need to support incorporated co-operativelike and unincorporated organisations, such as collectives, developed by racialized women. The innovative forms of co-operatives developed by women of Indigenous communities and immigrants from Southern countries are broadly inclusive and beneficial for all communities and the broader economy.

\section{The Author}

Ushnish Sengupta, is a social entrepreneur who has been involved in starting up a number of social enterprises. Ushnish has an Industrial Engineering and MBA education is currently completing a PhD at the Ontario Institute for Studies in Education (OISE), University of Toronto.

\section{Note}

1 The internationally prevalent term "indigenous" is utilised in the place of literature references to Aboriginal, Indian, and Native, unless a verbatim reference is required.

\section{References}

Acker, J (2006) "Inequality regimes gender, class, and race in organizations." Gender \& Society, 20(4): 441-464.

Acker, J (2005) Class questions: Feminist Answers. New York: Rowan \& LittleField

Acker, J (2000) "Revisiting class: Thinking from gender, race, and organizations." Social Politics: International Studies in Gender, State \& Society, 7(2): 192-214.

Adams, S (2011) The Most Prestigious Consulting Firms, August 25, [Online] www.forbes.com

Bacon, C M (2010) "A spot of coffee in crisis Nicaraguan smallholder co-operatives, fair trade networks, and gendered empowerment." Latin American Perspectives, 37(2): 50-71.

Blaszak, B J (2000) "The Gendered Geography of the English Co-operative Movement at the Turn of the nineteenth Century." Women's History Review, 9(3): 559-583.

Corntassel, J (2008) "Toward sustainable self-determination: Rethinking the contemporary Indigenousrights discourse" Alternatives 33(1): 105-132.

Crenshaw, K W (1995) "Mapping the margins: Intersectionality, identity politics, and violence against women of colour" in Creshaw, K, Gotanda, N, Peller, G and Thomas, K (Eds) Critical race theory: The key writings that formed the movement, New York: The New Press, pp357-383

Curl, J (2012) For all the people: Uncovering the hidden history of co-operation, co-operative movements, and communalism in America. 2nd edition, Oakland, CA: PM Press.

Eber, C E (1999) "Seeking Our Own Food: Indigenous Women's Power and Autonomy San Pedro Chenalho, Chiapas (1980-1998)." Latin American Perspectives, 26(3): 6-36.

Eccarius-Kelly, V (2006) “Guatemalan Women's Co-operatives and State Neglect.” Peace Review: $A$ Journal of Social Justice, 18(1): 37-43. 
Estey, K (2011) "Domestic Workers and Co-operatives: Beyondcare Goes Beyond Capitalism, A Case Study in Brooklyn, New York." Working USA, 14(3): 347-365.

Findlay, I, Popham, J and Ince, P (2014) Through the Eyes of Women: What a Co-operative Can Mean in Supporting Women during Confinement and integration. Saskatoon: Centre for the Study of Co-operatives and Community-University Institute for Social Research, available at www.usask.ca

Findlay, I M and Wuttunee, W (2007) "Aboriginal women's community economic development: Measuring and promoting success." IRRP Choices, 13(4): 4-26, available at www.irpp.org

Fisher, J (2013) "Fair or Balanced? The Other Side of Fair Trade in a Nicaraguan Sewing Co-operative." Anthropological Quarterly, 86(2): 527-557.

Gessler, A (2015) "A Formula for Freedom: The Utopian Promise of the 1940s New Orleans Co-operative Movement." Utopian Studies, 26(1): 58-78.

Giovannini, M (2015) "Indigenous community enterprises in Chiapas: A vehicle for Buen Vivir?" Community Development Journal, 50(1): 71-87.

Gitter, S R, Weber, J G, Barham, B L, Callenes, M and Valentine, J L (2012) "Fair trade-organic coffee co-operatives, migration, and secondary schooling in Southern Mexico." Journal of Development Studies, 48(3): 445-463.

Graefe, P (2006) "Social economy policies as flanking for Neoliberalism: Transnational policy solutions, emergent contradictions, local alternatives." Policy and Society, 25(3): 69-86.

Gute, D M, Siqueira, E, Goldberg, J S, Galvão, H, Chianelli, M and Pirie, A (2009) "The Vida Verde Women's Co-op: Brazilian immigrants organizing to promote environmental and social justice." American Journal of Public Health, 99(S3): S495-S498.

Harris, J and McLeod Rogers, J (2014) "Partnering to Build a Social Co-operative for Aboriginal Women Transitioning from Prison." Journal of Co-operative Studies, 47(1): 25-38.

Hunt, V, Layton, D and Prince, S (2015) Why diversity matters. McKinsey \& Company, February, available at www.mckinset.com

Incite! Women of Color Against Violence (2007) The revolution will not be funded: beyond the non-profit industrial complex. Cambridge, MA: South End Press.

International Co-operative Alliance (2015a) Co-operative identity, values \& principles. Available from www. ica.coop

International Co-operative Alliance (2015b) The Guidance Notes on the Co-operative Principles. Available www.ica.coop

Isaac, C B (1995) "Class stratification and co-operative production among rural women in central Mexico." Latin American Research Review, 30(2): 123-150.

Ketilson, L H and MacPherson, I (2001) A report on Aboriginal co-operatives in Canada: Current situation and potential for growth. Saskatoon, SK: University of Saskatchewan.

Kino-nda-niimi Collective (2014) (eds)The Winter We Danced: Voices from the Past, the Future, and the Idle No More Movement, Winnipeg, MB: Arbeiter Ring Publishing

Lans, C (2004) "Perceptions of female leadership from three co-ops in British Colombia." Review of International Co-operation, (97): 73-79

MacPherson, I (1979) Each for all: A history of the co-operative movement in English Canada, 1900-1945 (No 116), Ottawa, ON:Carleton University Press.

Mahood, G (2010) The Art of Colonialism: Inventing Canadian Identity Through Inuit Soapstone Carving. Unpublished Masters' Thesis, Concordia University available at www.spectrum.library.concordia.ca

Martin, N (2011) "There Is Abuse Everywhere: Migrant Nonprofit Organizations and the Problem of Precarious Work" Urban Affairs Review, 52: 780-807. DOI: 10.1177/1078087411428799

Mayoux, L (1993) "Integration is Not Enough: Gender Inequality and Empowerment in Nicaraguan Agricultural Co-operatives." Development Policy Review, 11(1): 67-90.

Mayoux, L (1992) "From Idealism to Realism: Women, Feminism and Empowerment in Nicaraguan Tailoring Co-operatives." Development and Change, 23(2): 91-114.

McElhinny, B (1998) "Co-operative culture: Reconciling equality and difference in a multicultural women's co-operative." Ethnos, 63(3-4): 383-412.

McMahon, M (2011) "Standard fare or fairer standards: Feminist reflections on agri-food governance." Agriculture and Human Values, 28(3): 401-412.

Meyers, J S and Vallas, S P (2016) "Diversity Regimes in Worker Co-operatives: Workplace Inequality under Conditions of Worker Control." The Sociological Quarterly, 57(1): 98-128.

Miller, G R (2012) "Gender Trouble: Investigating Gender and Economic Democracy in Worker Co-operatives in the United States." Review of Radical Political Economics, 44(1): 8-22.

Mitchell, M (1996) From talking chiefs to a native corporate elite: The birth of class and nationalism among Canadian Inuit. Montreal \& Kingston: McGill-Queen's University Press.

Mutersbaugh, T (2002) "Building Co-ops, Constructing Co-operation: Spatial Strategies and Development Politics in a Mexican Village." Annals of the Association of American Geographers, 92(4): 756-776. 
Mutersbaugh, T (1999) "Bread or chainsaws? Paths to mobilizing household labour for co-operative rural development in a Oaxacan village (Mexico)." Economic Geography, 75(1): 43-58.

Neal, R (1998) Brotherhood economics: Women and co-operatives in Nova Scotia. Cape Breton: Cape Breton University Press.

Nembhard, J G (2004) "Co-operative ownership in the struggle for African American economic empowerment." Humanity and Society 28(3): 298-321.

Nembhard, J G and Marsh, K (2012) "Wealth affirming policies for women of color." The Review of Black Political Economy, 39(3): 353-360.

Neu, D and Quantanilla, C (2008) "Market Discipline and Management Education A View From a Southern Women's Co-operative." Journal of Management Education, 32(6): 697-715.

Olson, J (1999) "Are artesanal co-operatives in Guatemala unraveling?" Human Organization, 58(1): 54-66.

Pattison, D and Findlay, I (2010) Self Determination In Action: The Entrepreneurship of the Northern Saskatchewan Trappers Association Co-operative. Saskatoon: University of Saskatchewan Centre for the Study of Co-operatives, available at www.usaskstudies.coop

Peterson, N D (2014) "We Are Daughters of the Sea: Strategies, Gender, and Empowerment in a Mexican Women's Co-operative." The Journal of Latin American and Caribbean Anthropology, 19(1) 148-167.

Radel, C (2011) "Becoming farmers: Opening spaces for women's resource control in Calakmul, Mexico." Latin American Research Review, 46(2) 29-54.

Schincariol McMurtry, L and McMurtry, J J (2015) Advancing Gender Equality: The Co-operative Way. Geneva: ILO available at www.ilo.org

Schmidt, E (2006) "Sustainable Community for Sustainable Development A Case Study of the Mujeres Reunidas Co-operative in Hidalgo, Mexico." Journal of Developing Societies, 22(4): 379-400.

Schneiberg, M (2010) "Toward an Organizationally Diverse American Capitalism-Co-operative, Mutual, and Local, State-Owned Enterprise." Seattle University Law Review, 34: 1409-1434.

Sengupta, U (2015) "Indigenous Co-operatives in Canada: The Complex Relationship Between Co-operatives, Community Economic Development, Colonization, and Culture." Journal of Entrepreneurial and Organizational Diversity, 4(1): 121-152.

Stephen, L (2005) "Women's Weaving Co-operatives in Oaxaca An Indigenous Response to Neoliberalism." Critique of Anthropology, 25(3): 253-278.

Sumner, J (2005) "Small is Beautiful: The Responses of Women Organic Farmers to the Crisis in Agriculture." Canadian Woman Studies, 24(4): 78-84.

Susman, P and Schneider, G (2008) "Institutional challenges in the development of the world's first worker-owned free trade zone." Journal of Economic Issues, 42(2): 489-498.

Taylor, D E (2014). The state of diversity in environmental organizations: Mainstream NGOs, Foundations, Government Agencies. Report prepared for Green 2.0, Ann Arbor, MI: University of Michigan, available at www.diversegreen.org

Theis, L and Ketilson, L H (1994) Research for action: women in co-operatives. Saskatoon:University of Saskatchewan Centre for the Study of Co-operatives

Trauger, A, Sachs, C, Barbercheck, M, Brasier, K and Kiernan, N E (2010) "Our market is our community: women farmers and civic agriculture in Pennsylvania, USA." Agriculture and Human Values, 27(1): 43-55.

Truehaft, S, Scoggins J and Tran J (2014) The Equity Solution: Racial Inclusion is Key to Growing A Strong New Economy. PolicyLink Research brief, available at www.policylink.org

Van Vliet, M (2006) Networking Diversity: Including Women and Other Under-represented Groups in Co-operatives. Saskatoon: University of Saskatchewan Centre for the Study of Co-operatives.

Vargas-Cetina, G (2005) "Anthropology and Co-operatives From the Community Paradigm to the Ephemeral Association in Chiapas, Mexico." Critique of Anthropology, 25(3): 229-251. 